\title{
Thyroid Gland Hurthle Cell Carcinoma
}

National Cancer Institute

\section{Source}

National Cancer Institute. Thyroid Gland Hurthle Cell Carcinoma. NCI Thesaurus. Code C4946.

A follicular carcinoma of the thyroid gland, characterized by the presence of large cells with eosinophilic granular cytoplasm and pleomorphic nuclei with prominent, eosinophilic nucleoli. The nuclear features that characterize the papillary carcinomas of the thyroid gland are absent. 